УДК 341.6

DOI https://doi.org/10.32849/2663-5313/2020.5.59

Аліна Левенець,

студентка магістратури

Начіонального юридичного університету імені Ярослава Мудрого

\title{
ЗАГАЛЬНА ХАРАКТЕРИСТИКА ПРОЦЕДУРИ ВИКОНАННЯ РІШЕНЬ ЄВРОПЕЙСЬКОГО СУДУ 3 ПРАВ ЛЮДИНИ В УКРАЇНІ
}

Забезпечення та гарантування прав людини і громадянина не можливе без ефективного механізму розгляду справ у суді. При иьому є необхідність не лише захисту порушеного права, але іналежного виконання судового рішення, що є важливим елементом контрольного механізму Конвениії про захист прав людини та основоположних свобод. У разі порушених державою прав фізичних і юридичних осіб наявні гарантї їх відновлення та створення необхідних заходів для неможливості повторення таких порушень у майбутньому. Ця стаття присвячена проблемам виконання рішень Свропейського суду з прав людини в Україні. Зокрема, загальній характеристиці прочедури виконання та особливостям правового регулювання такого питання. Варто зазначити, що законодавчо виконання рішень Суду хоч іперебуває в тісній взаємодії органів Ради Європи та держав-учаснииь, але не є досить досконалим та потребує модернізаиії, спираючись на зарубіжний досвід європейських країн. Виконання остаточних рішень Суду $\epsilon$ досить тривалим та складним прочесом не лише для стягувача, але й для органів державної влади, а тому необхідно приділяти значну увагу спрошенню такої процедури. Негативний вплив на виконання рішень Суду справляє відсутність чіткої взаємодії між органами, від яких залежить виконання судового рішення. Важливим складником виконання рішень Свропейського суду з прав людини є обов'язковість визначення сум для щорічної реалізачії ухвал Європейського суду з прав людини у державному бюджеті. Закон Украйни «Про виконання рішень та застосування практики Європейського суду з прав люди ни» не передбачає таких зобов'язань, саме тому виникають проблеми під час виконання рішень щодо питань виплати. Необхідно підкреслити, що останніми роками спостерігається тенденція зменшення сум державного боргу перед громадянами в частині виконання рішень Європейського суду з прав людини. Повною мірою проаналізовано законодавство Украйни щодо виконання рішень Європейського суду з прав людини та іноземних держав з ивого питання, визначено основні напрями дослідження та запропоновано певні підходи та варіанти вирішення вищезазначеного питання.

Ключові слова: виконання рішень, процедура виконання, суд, права людини, виплата відшкодування, органи державної влади, державний бюджет, національне законодавство.

Постановка проблеми. Виконання рішень Європейського суду з прав людини $€$ обов'язком України відповідно до Конвенції про захист прав людини та основоположних свобод. Важливим аспектом у гарантуванні цих прав $є$ створення належної законодавчої основи, а також особливостей іï упорядкування, яка б забезпечила швидке та дієве виконання рішень Суду.

Метою цієї статті є дослідження питання, що стосується процедури виконання рішень Свропейського суду з прав людини у разі порушених прав фізичних та юридичних осіб в Україні.

Аналіз останніх досліджень і публікацій. Методологічним підгрунтям дослідження стали методичні напрацювання провідних українських учених, практика Європейського суду з прав людини, матеріали періодичних видань, ресурси Internet, норма- тивно-правові акти. Проблеми зазначеної тематики у своїх наукових працях висвітлювали О.О. Кочура, У.З. Коруц, Н.В. Камінська, Я.І. Півнев, Д.О. Фещенко та інші. Під час написання роботи використовувалися загальнофілософські методи дослідження.

Виклад основного матеріалу. Важливим етапом на шляху розбудови України як демократичної, правової держави стала ратифікація Конвенції про захист прав людини та основоположних свобод від 17 липня 1997 р. (набула чинності 11 вересня того ж року) Відповідно до п. 1 ст. 46 Конвенції держава-учасниця зобов'язується виконувати остаточні рішення Європейського суду з прав людини (далі - ССПЛ або Суд) у будь-яких справах, в яких вона є стороною [1]. У преамбулі Конвенції зазначається, що її мета полягає в колективному забезпеченні відповідних прав і свобод. Це зумовило необхідність заснування ЄСПЛ, покликаного контролю- 
вати дотримання державами-учасницями прав і свобод людини та громадянина.

Україна визнала юрисдикцію ЄСПЛ 3 метою створення в схожих правовідносинах однорідної судової практики для забезпечення більш повної інтеграції до європейського правового простору [2, с. 49]. Зі змісту ст. 9 Конституції України випливає, що Конвенція є складником національного законодавства, оскільки Верховна Рада дала згоду на їі обов'язковість. Важливою гарантією забезпечення права на справедливий судовий розгляд $є$ виконання Україною судових рішень.

3 огляду на особливості вітчизняного законодавства, слід зазначити, що виконання остаточних рішень Суду є тривалим та складним процесом не лише для стягувача, але й для органів державної влади. Практика виконання Україною рішень ЄСПЛ відрізняється від аналогічної практики інших держав-учасниць.

Процедура виконання остаточних рішень Суду має специфіку. Після вжиття всіх належних заходів індивідуального та загального характеру на виконання відповідного остаточного рішення ЄСПЛ держава надає інформацію, що в майбутньому слугує основою для ухвалення на засіданні Комітету міністрів Ради Європи (далі - КМ РЕ) резолюції. У такому разі рішення ССПЛ можна вважати виконаним.

У період з 2010 по 2019 роки було зареєстровано 2120 справ, що виявили структурні та/або системні проблеми на національному рівні. 2287 провідних справ було закрито (відповідно, ступінь закриття справ становив 108\%). У період з 2000 по 2010 роки було зареєстровано 1470 нових провідних справ, 602 з яких було закрито (ступінь закриття провідних справ становив лише 41\%). Станом на 31 грудня 2019 р. на розгляді в КМ РЄ перебували 5231 постанова і рішення на різних стадіях виконання. У щорічній доповіді КМ РЄ за 2019 р. зазначено, що 635 постанов 3 провідних справ очікують виконання не менше 5 років, тоді як у 2016 р. таких справ було 720 [3].

У своїй діяльності КМ РЄ керується Правилами щодо контролю за виконанням рішень ЄСПЛ та умов дружнього врегулювання від 10 травня 2006 року. У разі недодержання державою-учасницею своїх зобов'язань щодо виконання остаточного рішення суду Комітет Міністрів може порушити перед Судом це питання. У разі виявлення порушень Суд може застосувати санкції, а саме: позбавити державу права голосу, припинити членство тощо. Так, у рішенні Великої палати ССПЛ у справі «Скоццарі і Дж'юнта проти Італії» вказано на зобов'язання держав-учасниць стосовно здійснення необхідних заходів для виконання таких рішень: зі ст. 46 Конвенції випливає зобов'язання держав-учасниць виконувати остаточні рішення Суду в будьякій справі, у якій вони є сторонами, тоді як нагляд за їх виконанням здійснюе КМ РЕ [4]. У держави-учасниці виникає правовий обов'язок не лише виплатити суми справедливої сатисфакції, але й реалізувати у національній правовій системі загальні та/або індивідуальні заходи, спрямовані на усунення порушень, виявлених Судом, і їх наслідків.

Відповідно до Закону України «Про виконання рішень та застосування практики Свропейського суду з прав людини» виконання рішень ЄСПЛ здійснюється за рахунок коштів державного бюджету [5]. Сума державного боргу перед громадянами на початок 2019 р. становила понад 4 мільярди гривень. Якщо у 2015 році на виконання рішень ЄСПЛ по суті скарг з державного бюджету України було сплачено близько 640 млн грн, то у 2018 р. загальна сума зменшилась до 32 млн грн.

Отже, є позитивна динаміка не лише зменшення сум виплат, але й кількості скарг до ЄСПЛ. Таким чином, можна констатувати прогрес у реалізації судової реформи, що позитивно позначилося на забезпеченні прав людини у вітчизняних судах. Безумовно, було б помилково стверджувати, що в Україні відсутні проблеми у цьому питанні: для зменшення кількості скарг i, як наслідок, належного виконання рішень ССПЛ необхідно і надалі вносити зміни до законодавчих актів та вдосконалювати практику його застосування. Важливо також зберігати взаємодію між Радою Європи та державамиучасницями [3].

Відповідно до Закону «Про виконання рішень та застосування практики Свропейського суду з прав людини» виконанням рішень ССПЛ у справах щодо України $€$ : виплата відшкодування, присудженого Судом; вжиття додаткових заходів індивідуального характеру, спрямованих на усунення конкретного порушення, визначеного в рішенні Суду; вжиття заходів загального характеру.

Виконання рішень ЄСПЛ у частині виплати відшкодування покладено на органи державної виконавчої служби. Відповідальними за здійснення виплат у зарубіжних країнах є: Федеральне міністерство фінансів (ФРН), Міністерство юстиції (Португалія, Литва), Міністерство фінансів (Естонія), Міністерство економіки (Італія) та аналогічні за компетенцією урядові органи інших держав-учасниць [7, с. 118]. 
Під відшкодуванням відповідно до ст. 1 Закону України «Про виконання рішень та застосування практики Європейського суду з прав людини» розуміється:

а) сума справедливої сатисфакції, визначена рішенням ЄСПЛ відповідно до ст. 41 Конвенції;

б) визначена в рішенні ЄСПЛ щодо дружнього врегулювання або в рішенні Суду про схвалення умов односторонньої декларації сума грошової виплати на користь стягувача.

Найменш проблематичним $є$ виконання рішень ЄСПЛ щодо виплати сум справедливої сатисфакції. Зазвичай кошти сплачують вчасно. Державне казначейство України з метою виконання рішення ЄСПЛ здійснює списання коштів з відповідної бюджетної програми державного бюджету. Закон про виконання рішень ЄСПЛ не передбачає зобов'язань стосовно визначення сум для щорічної реалізації ухвал ЄСПЛ у державному бюджеті, саме тому виникають проблеми під час виконання рішень щодо виплати. На необхідність передбачення коштів на виконання рішень ССПЛ в окремій бюджетній програмі вказано лише в перехідних положеннях Закону України «Про виконання рішень та застосування практики Свропейського суду з прав людини».

У пілотному рішенні «Юрій Миколайович Іванов проти України» зазначається, що держава «має значну системну проблему, оскільки у ній не виконуються рішення національних судів, за виконання яких вона несе відповідальність» [8]. Якщо виконання рішення ускладнюється проблемою його тлумачення, то КМ РС може просити Суд дати відповідне роз'яснення. Рішення про таке звернення приймається $2 / 3$ голосів Комітету Міністрів.

Необхідно зазначити, що ЄСПЛ не є судом четвертої інстанції в судовій системі України, оскільки він лише констатує порушення певного права людини та присуджує суму справедливої компенсації. ЄСПЛ не видає виконавчих листів, а тому особа не повинна самостійно пред'являти рішення до виконання або в будь-який спосіб його стимулювати. Держава зобов'язана виконувати рішення Суду на користь особи.

Слід підкреслити, що одним із шляхів вирішення, оптимізації та узагальнення актуальної інформації щодо сум грошових коштів, необхідних для виконання рішень ЄСПЛ, є важливість створення і ведення реєстру відповідних рішень та заборгованостей за ними, оскільки натепер фактично відсутня будь-яка достовірна інформація щодо необхідних для забезпечення виконання рішень судів коштів. Без такої інформації неможливо точно розрахувати та закласти у бюджеті відповідні асигнування [2, с. 53].

Важливим складником виконання рішень суду є застосування додаткових заходів індивідуального характеру. Відповідно до Закону України «Про виконання рішень та застосування практики Європейського суду 3 прав людини» додатковими заходами індивідуального характеру, що застосовує держава, є такі:

а) відновлення настільки, наскільки це можливо, попереднього юридичного стану, який стягувач мав до порушення Конвенції (restitutio in integrum);

б) інші заходи, передбачені в рішенні.

Відновлення попереднього юридичного стану стягувача здійснюється шляхом повторного розгляду справи судом, включаючи відновлення провадження у справі або повторного розгляду справи адміністративним органом. У своїх рішеннях ЄСПЛ також може вказати на окремі заходи індивідуального характеру, яких держава має вжити для виконання рішення Суду.

Ще одним складником виконання рішень ЄСПЛ є застосування заходів загального характеру, що застосовуються з метою забезпечення додержання державою положень Конвенції, порушення яких встановлене рішенням, забезпечення усунення недоліків системного характеру, які лежать в основі виявленого Судом порушення, а також усунення підстави для надходження до Суду заяв проти України, спричинених проблемою, що вже була предметом розгляду в Суді.

Відповідно до ч. 2 ст. 13 Закону «Про виконання рішень і застосування практики Європейського суду 3 прав людини» заходами загального характеру є заходи, спрямовані на усунення зазначеної в рішенні системної проблеми та її першопричини, а саме: a) внесення змін до чинного законодавства та практики його застосування; б) внесення змін до адміністративної практики; в) забезпечення юридичної експертизи законопроєктів; г) забезпечення професійної підготовки 3 питань вивчення Конвенції та практики Суду прокурорів, адвокатів, працівників правоохоронних органів, працівників імміграційних служб, інших категорій працівників, професійна діяльність яких пов'язана із правозастосуванням, а також із триманням людей в умовах позбавлення свободи; г) інші заходи, які визначаються (за умови нагляду з боку КМ РС) державою-відповідачем відповідно до Рішення з метою забезпечення усунення недоліків системного характеру, припинення спричинених цими недоліками порушень Конвенції та забезпечення максимального відшкодування наслідків цих порушень. 
Протягом десяти днів від дня отримання повідомлення про набуття рішенням ЄСПЛ статусу остаточного Орган представництва надсилає стягувачу повідомлення 3 роз'ясненням його права подати до Державної виконавчої служби заяву про виплату відшкодування, в якій мають бути зазначені реквізити банківського рахунка для перерахування коштів, а також надсилає до Державної виконавчої служби оригінальний текст і переклад резолютивної частини остаточного рішення ЄСПЛ щодо справедливої сатисфакції, дружнього врегулювання, про схвалення умов односторонньої декларації у справі проти України. Державна виконавча служба упродовж десяти днів з дня надходження відповідних документів відкриває виконавче провадження. Неподання стягувачем заяви про виплату відшкодування не $є$ перешкодою для виконання рішення ЄСПЛ.

Як тільки остаточне рішення суду передано КМ Р€, останній запрошує державувідповідача проінформувати його про кроки, зроблені для виплати компенсації, призначеної Європейським судом з прав людини, і в разі необхідності про заходи індивідуального та загального характеру, прийняті для виконання рішення. Переконавшись, що держава прийняла всі необхідні заходи для виконання рішення, КМ Р€ приймає резолюцію про те, що його функції виконані.

\section{Висновки}

Можна впевнено сказати, що рішення ЄСПЛ мають слугувати для органів публічної влади, їх посадових осіб орієнтирами у сфері гарантування прав і свобод людини, що є запорукою дотримання європейських демократичних стандартів та цивілізаційного розвитку нашої держави. Одним із чинників, які негативно впливають на виконання рішень Суду, є відсутність чіткої взаємодії між органами, від яких залежить виконання судового рішення. Вирішення вищезазначеного питання потребує детального аналізу законодавства, зокрема податкового, та усунення його прогалин. Важливим $є$ також підвищення кваліфікації посадових осіб, відповідальних за належне виконання рішень Суду, шляхом міжнародного співробітни- цтва та запозичення досвіду провідних країн світу, встановлення покарання за їх бездіяльність, а також ведення Єдиного реєстру виконання рішень ЄСПЛ. Таким чином, виконання рішень ССПЛ є ключовим елементом у забезпеченні прав людини та їх дотриманні, принципів демократії і верховенства серед країн-членів.

\section{Список використаних джерел:}

1. Конвенція про захист прав людини і основоположних свобод від 04.11.1950. URL: https:// zakon.rada.gov.ua/laws/show/995_004 (дата звернення: 27.03.2020)

2. Коруц У.З. Окремі питання виконання рішень Європейського судуз прав людини. Актуальні проблеми правознавства. 2016. Вип. 1. С. 49-53. URL: http://dspace.tneu.edu.ua/bitstream/316497/6647/1 \%D0\%9A\%D0\%BE\%D1\%80\%D1\%83\%D1\%86\%20 \%D0\%A3.pdf (дата звернення: 27.03.2020).

3. Supervising execution of ECHR judgments 2019 report shows significant progress, but challenges remain. URL: https://www.coe.int/ru/web/ portal/-/supervising-execution-of-echr-judgments2019-report-shows-significant-progress-butchallenges-remain (дата звернення: 27.03.2020).

4. Рішення у справі «Скоццарі та Дж'юнта проти Італії» : Комюніке Секретаря Суду. Практика Європейського суду з прав людини. Рішення. Коментарі. 2000. № 3. URL: http://eurocourt. in.ua/Article.asp?AIdx=278.

5. Про виконання рішень та застосування практики Європейського суду з прав людини : Закон України від 23.02.2006 № 3477-IV / Верховна Рада Украйни. URL: https://zakon.rada.gov.ua/ laws/show/3477-15 (дата звернення: 29.03.2020).

6. Інформація щодо виконання рішень Європейського суду 3 прав людини у справах проти України. URL: https://minjust.gov. $\mathrm{ua} / \mathrm{m} /$ informatsiya-schodo-vikonannya-rishenevropeyskogo-sudu-z-prav-lyudini-u-spravah-protiukraini (дата звернення: 03.04.2020).

7. Кочура О.О. Окремі аспекти виконання Україною рішень Європейського суду з прав людини. Науковий вісник Ужгородського начіонального університету. Серія «Право». 2015. Вип. 32(1). С. 116-121. URL: http://nbuv.gov. ua/UJRN/nvuzhpr 2015 32\%281\%29 28 (дата звернення: 03.04.2020).

8. Справа «Юрій Миколайович Іванов проти України» (Заява № 40450/04). URL: https:// zakon.rada.gov.ua/laws/show/974_479 (дата звернення: 04.04.2020)

Providing and guaranteeing human and citizen's rights are not possible without an effective court case mechanism. At the same time, exists a necessity not only for the protection of the violated right, but also for the properenforcement of thejudgment, whichisanimportantelement of the controlmechanismof the Convention for the Protection of Human Rights and Fundamental Freedoms. In the case of state violations of the rights of individuals and legal entities, there are guarantees for their restoration and the creation of the necessary measures to prevent such violations in the future. This article deals with the problems of the implementation of judgments of the European Court of Human Rights in Ukraine. In particular, the general characteristics 
of the execution procedure and the specific legal regulation of the issue. It is worth noting that the legislative implementation of the Court's decisions, although closely coordinated by the Council of Europe bodies and the participating States, is not yet sufficiently advanced and needs to be modernized, drawing on foreign experience in European countries. Enforcement of the final decisions of the Court is a lengthy and complicated process not only for the claimant but also for the public authorities. Considerable attention should be paid to simplifying the procedure. The negative impact on the enforcement of the Court's decisions depends on the lack of clear interaction between the government agencies on which the enforcement of the judgment depends. An important component of the implementation of the decisions of the European Court of Human Rights is the obligation to determine the amounts for the annual implementation of the European Court of Human Rights' decisions in the state budget. The law "On the enforcement of decisions and the application of the case law of the European Court of Human Rights" does not provide for such obligations, that is still the reason why problems arise while executing payment decisions. It should be emphasized that in recent years there has been a tendency to reduce the amount of public debt to citizens in the implementation of the decisions of the European Court of Human Rights. The legislation of Ukraine on the implementation of the decisions of the European Court of Human Rights and foreign states on this issue has been fully analyzed, the main directions of the research have been identified and some approaches and options for solving the above issue have been proposed.

Key words: enforcement of decisions, procedure of execution, court, human rights, payment of compensation, public authorities, state budget, national legislation. 